\title{
Urszula Kowalska-Nadolna
}

\section{Między tradycją a postępem,} historią a nowoczesnością, morzem a lądem

Places have deep associations; places have story to tell... Robert Burden

W 2015 roku, nakładem wydawnictwa Ashgate Publishing Limited, ukazała się książka brytyjskiego badacza (autora publikacji poświęconych twórczości Josepha Conrada, Davida Herberta Lawrence'a oraz literackim obrazom miejsc i przestrzeni) Roberta Burdena, zatytułowana Travel, Modernism and Modernity (Podróż, modernizm i nowoczesność).

Celem studium Burdena było odkrywanie znaczeń tekstów podróży powstałych w epoce modernizmu. Autor swoje rozważania opiera na wybranych literackich i nieliterackich dziełach pięciorga anglojęzycznych pisarzy - Josepha Conrada (1857-1924), Edwarda Morgana Forstera (1879-1970), Davida Herberta Lawrence'a (1885-1930), Henry'ego Jamesa (1843-1916) i Edith Wharton (1862-1937). Ich twórczość wielokrotnie stawała się przedmiotem zainteresowania literaturoznawców, tym jednak, co odróżnia pracę Burdena od analiz dotąd dostępnych czytelnikowi, jest jej bardzo wyraźna wielowątkowość i szerokie kontekstowe spojrzenie. Burden prezentuje sylwetki
K r y $\quad$ t $y$ k i : Robert Burden, Travel, Modernism and Modernity, Farnham 2015.

bohaterów swojej książki, podkreśla znaczenie w ich tekstach wątków autobiograficznych (nie tylko związanych z podróżowaniem), kontekstowo analizuje miejsca ich twórczości na tle epoki, a badając wpływ odwołań do epok wcześniejszych, wskazuje przede wszystkim tradycje oświeceniowe i romantyczne. Tylko pozornie punktem łączącym wybrane teksty jest podróż. W rzeczywistości całe studium brytyjskiego badacza poświęcone zostało wskazywaniu paraleli, korespondencji, a także cech oryginalnych, swoistych, istotnych różnic w pisarstwie pięciorga anglojęzycznych autorów.

Burden analizuje dzienniki, eseje, notatki, przewodniki oraz różnorodne teksty literackie, poszukując motywu podróży w wybranych pracach Conrada, Forstera, Lawrence'a, Jamesa i Wharton. Określa rolę, jaką odgrywa motyw podróży oraz to, w jakim stopniu wpływa on na tekst jako trop literacki, dominanta tematyczna, a także model narracyjny, odzwierciedlający się w strukturze utworu. W interpretacji Burdena podróż w przekazie artystycznym staje się metaforą poszukiwania tożsamości (indywidualnej, narodowej, kulturowej...) w epoce głębokiego kryzysu. Krytyczne spojrzenie na modernizm i nowoczesność dopełnia obecna w wybranych tekstach 
świadomość kolonizatorskich tradycji charakteryzujących brytyjską i amerykańską kulturę.

Kluczowym pojęciem towarzyszącym interpretacji wybranych tekstów jest, oczywiście, sam modernizm (modernism), przez Burdena pojmowany w szerszym ujęciu za Timem Armstrongiem czy Michaelem Levensonem. W rozważaniach Burdena znaczące miejsce zajmuje ponadto kwestia stylistycznej i estetycznej, przełamującej modernistyczne konwencje, różnorodności, obecnej między innymi w opisach pejzaży, krajobrazów czy budowli.

Tytułowa nowoczesność (modernity) stanowi dla Burdena immanentny element modernistycznego, dychotomicznego myślenia o świecie (s. 3). Jak podkreśla we wstępie, istotne dla jego rozważań założenie wynika z badań Steve'a Gilesa, przybliżającego modernistyczną dyskusję nad rozumieniem nowoczesności. Burden przypomina o typowym dla schyłku XIX i początku XX wieku niejednoznacznym spojrzeniu na nowoczesność, która z jednej strony przynosi postęp technologiczny i naukowy, pozwalający człowiekowi na przejęcie kontroli nad światem naturalnym, z drugiej zaś oddala go od tradycyjnych wartości, które gwarantują poczucie tożsamości (s. 3). „Modernistyczna krytyka nowoczesności jest reprezentowana przez wszystkich pisarzy omawianych w tej książce" stwierdza Burden. Podkreśla także za Baudelaire'em, że współczesną egzystencję charakteryzuje „ulotność, ucieczka i przypadkowość". Modernistyczna utrata tradycyjnych wartości prowadzi do załamania się konwencji literackich - stąd widoczne w twórczości wybranych pisarzy dążenie do przywrócenia literaturze klasycznych narracji. Zwraca uwage na podobną w tym zakresie strategię czworga pisarzy, tj.: Conrada, Forstera, Jamesa i Wharton, którzy za pośrednictwem estetycznych i formalnych środków próbują powrotu do tradycyjnych wartości. Z artyzmem opisu odwiedzonych przez pisarzy miejsc, przestrzeni, miast i zabytków, z radością postrzegania (co istotne, oczami podróżnika, nie turysty - na tę, niezwykle wyraźną w modernistycznym pisarstwie, opozycję Burden wskazuje wielokrotnie) wiążą się także wartości moralne - wywołane obserwacją sztuki czy architektury. Poczucie harmonii (nie tylko estetycznej) miałoby stać się fundamentem współczesnej cywilizacji.

W obszernym wstępie autor rekapituluje także główne teorie dotyczące modernizmu, formułowane w drugiej połowie XX wieku, ukazujące niezwykle zróżnicowane ujęcia problematyki. Autor przywołuje między innymi koncepcje Rogvalda Eysteinssona (modernizm jako przedmiot zainteresowania wielu ugrupowań), Rolanda Barthes'a (zwracającego uwage przede wszystkim na język jako tworzywo literackie), Ortegi y Gasseta (piszącego o dehumanizacji sztuki), Györgya Lukácsa (zajmującego się głównie dekadentyzmem), Theodora Adorna (zwracającego uwage na radykalny modernistyczny atak na nowoczesność, przejawiający się w strategiach estetyzacyjnych), Richarda Shepparda (proponującego trzy różne strategie w odpowiedzi na pytanie „czym jest modernizm?”, z uwzględnieniem kontekstów politycznych, społecznych, historycznych i literackich) czy niemieckich badaczy (z Jürgenem Habermasem na czele), uważających modernizm za kontynuację tradycji oświeceniowej (s. 5-6).

$\mathrm{Na}$ tle tak szerokiej i zróżnicowanej literatury przedmiotu, przywoływanej przez autora, Travel, Modernism and Modernity jest głosem, który do toczącej się od kilku dekad dyskusji na temat znaczenia modernizmu w historii światowej literatury dodaje marginalizowany we wcześniejszych opracowaniach motyw podróży, funkcjonujący w literaturze epoki zarówno jako model narracyjny, jak i trop literacki. Burden dyskutuje ze stwierdzeniem, jakoby wpływ motywu podróży na twórczość literacką nasilił się dopiero w okresie późnego modernizmu, w latach 30. XX wieku, podkreśla, że ten topos, struktura 
wędrówki odzwierciedlona w kompozycji tekstu, jak również istotna rola topografii w przestrzeni dzieła literackiego (czy szerzej - artystycznego) są obecne już we wczesnym pisarstwie epoki, w której podróżopisarstwo ulega (na przekór wzorcom wiktoriańskim) znacznej subiektywizacji, staje się impresjonistyczne, skoncentrowane jest przede wszystkim na wrażeniu, przeżyciu, doświadczeniu i świadomości podróżującego, nie zaś na samej podróży. Badawcze zainteresowania Burdena i jego wnikliwa analiza prezentowanego w książce dorobku wybranych anglojęzycznych pisarzy wynikają z obserwacji stosowanych w ich twórczości zabiegów dekonstruujących konwencjonalne pisarstwo podróży, jednocześnie jednak potwierdzających archetypiczność motywów wędrówki, pielgrzymki, ucieczki, poszukiwania, odkrywania, pogoni... A także charakterystycznych dla epoki wątków opuszczenia ojczyzny, emigracji, wykorzenienia.

Już we wstępie Burden sygnalizuje pewne podobieństwa biografii oraz tekstów wychodzących spod pióra omawianych w pracy pisarzy, podkreśla wyraźną różnicę między podróżą (travel) i turystyką (tourism). Masowe, komercyjne wyjazdy turystyczne, nastawione na powierzchowne obserwacje, niepogłębione, właściwie pozbawione aspektu poznawczego zwiedzanie symbolizują według Burdena "ciemną stronę" modernizmu. Różne typy podróży realizowane (dosłownie i w przenośni, w życiu i w literaturze) przez Conrada, Forstera, Lawrence'a, Jamesa i Wharton stają się reprezentacją różnych typów poznania i odmiennych poziomów świadomości na temat inności, obcości. Burden zwraca uwage na fakt, że symboliczne przekraczanie granic (noszące znamiona przygody, jak u Conrada czy romantycznej pielgrzymi, jak u Forstera czy Lawrence'a) staje się punktem wyjścia do rozważań i obserwacji na temat amerykańskiej i brytyjskiej kolonizacji, różnic społecznych, rasowych, kulturowych, światopoglądowych, tożsamościowych. Zdaniem autora, istotnym składnikiem i wyróżnikiem zarówno dzienników podróży, przewodników, jak i innych tekstów wybranych autorów jest doświadczenie podróży uciekające od kiczu i stereotypu, odmienne od „powszechnego”, „masowego”, które w sposób sztuczny i siłowy redukuje i upraszcza poznawcze doznania. Spojrzenie takie zapewnia perspektywa literacka i artystyczna (por. s. 11).

Jak twierdzi Burden, „miejsca mają głębokie powiązania; miejsca mają historię do opowiedzenia" (s. 13). W każdym z rozdziałów badacz szczegółowo omawia różne historie „opowiedziane” przez przestrzenie obecne w tekstach Conrada, Forstera, Lawrence'a, Jamesa i Wharton. Owe opowieści dotyczą ważnych dla modernistycznej świadomości wielkich miast (Paryż, Londyn, Berlin, Nowy Jork, Chicago) oraz innych topograficznych reprezentacji - budowli, pejzaży, ruin, mórz, lasów... Burden podkreśla również, że krytyczny stosunek do ojczyzny, widzianej z obcej, zewnętrznej perspektywy, także stanowi analogię łączącą pisarstwo podróżnicze wybranych twórców. Wnikliwie uzasadnia interpretacje licznymi przykładami z tekstów, analizuje w pięciu rozdziałach, poświęconych konkretnym pisarzom, stosowane przez nich „przestrzenne praktyki” (spacial practices), korzystające z kulturowych znaczeń przypisywanych konkretnym miejscom i rejonom. Interesującym punktem dociekań autora jest towarzysząca niemal każdemu rozdziałowi refleksja pozaliteracka, skupiona między innymi na filozoficznych, psychologicznych i socjologicznych aspektach podróży. W tych miejscach swoich rozważań Burden nierzadko odwołuje się do ustaleń Freuda czy Lacana, w których podróż jest traktowana jako wyraz braku zadowolenia z miejsca, w jakim się żyje, staje się także metodą samopoznania. Transgresywne i transformatywne wymiary wędrówki łączą się z widocznym w modernistycznej twórczości przekonaniem, że ktoś, kto udał się w podróż, powinien powrócić do domu odmieniony. Pragnienie podróży typowe dla pisarzy i ich literackich bohaterów wywołuje także konieczność zmierzenia się z obyczajową konwencją charakterystyczną dla 
angielskiego i amerykańskiego społeczeństwa końca XIX oraz początku XX wieku. Niejednoznaczne stanowisko w dyskusji nad nierównym statusem społecznym kobiet i mężczyzn zajmuje w swojej twórczości także jedyna kobieta, której dorobek jest przez Burdena omawiany - Edith Wharton. Poświęcony jej pisarstwu ostatni rozdział stanowi swoistą klamrę z najobszerniejszą częścią pierwszą, w której wiodącym motywem stała się charakterystyczna dla Josepha Conrada fascynacja morzem i przebijające przez nią przeświadczenie, że podróż pozostaje domeną mężczyzn. Kwestie płciowości (oraz seksualności) nie są obce także twórczości pozostałych autorów - jak na przykład w przypadku Jamesa, dla którego kryzys kulturowej integralności i rozpad tradycyjnych wartości staje się również kryzysem męskości.

Trudno na kilku stronach przeanalizować erudycyjne dzieło Roberta Burdena. Jego rozważania, mimo że dotyczą cenionych i uznanych za czołowych przedstawicieli anglojęzycznej literatury modernistycznej artystów, przynoszą nowe spojrzenie na ich twórczość, uzupełniaja dotychczas powstałe interpretacje. Wielopłaszczyznowość tekstu, głęboka analiza, wnikliwość w docieraniu do podróżniczych wątków są jednymi z największych zalet recenzowanej pracy. Książka jest także studium rekapitulującym dotychczasowe ustalenia na temat epoki literackiej i jej czołowych przedstawicieli.

Pierwszy rozdział zatytułowany Joseph Conrad: Stories of the Sea and the Land przybliża problematykę wybranych powieści Josepha Conrada, w których pojawia się podróż, ze szczególnym uwzględnieniem toposu morza. Analizując między innymi teksty Heart of Darkness, A Personal Record, The Mirror of the Sea, The Nigger of the "Narcissuss", Burden zwraca uwage przede wszystkim na silną więź z morzem, wynikającą rzecz jasna z osobistych doświadczeń autora. Morze stanowi w twórczości Conrada przestrzeń ideologiczną i imaginacyjną. Badacz dużo miej- sca poświęca specyficznemu mikrokosmosowi, jaki stanowi życie na pokładzie oraz opozycji morza i lądu, w której ten drugi bywa rozumiany jako przestrzeń niepożądana, nie-miejsce, zaprzeczenie domu. W dalszej części rozdziału Burden analizuje charakterystyczne dla malarstwa impresjonistycznego zabiegi obecne w twórczości Conrada, oceniając jednak impresjonizm pisarza raczej w kategoriach zradykalizowanego realizmu (s. 37). Podróż nie pozostaje bez wpływu również na samą strukturę jego narracji, w ramach której pojawiają się archetypiczne echa mitycznych wędrówek przez morza, a także powtarzalne odwołania do mitologii starożytnej (np. w obrazowaniu morza jako lustra z opowieści o Narcyzie). Conrad dekonstruuje tradycyjne i znane od wieków klisze pisarstwa podróżniczego oraz powieści przygodowych, które, jak wskazuje Burden, stanowiły jego ulubione lektury w młodości. Charakterystyczne dla interpretacji Burdena odwołania do osobistych doświadczeń pisarza widoczne są, oczywiście, we wszystkich rozdziałach, w których funkcję wstępu pełnią przybliżające także kontekst epoki informacje biograficzne, obejmujące między innymi pochodzenie, sytuację życiową, destynacje, powody i motywacje odbytych podróży. Podobnie jak w najsłynniejszym dziele Conrada (Jądro ciemnoścl) istotnym punktem granicznym prywatnej i pisarskiej egzystencji innych twórców przedstawianych przez Burdena, jest obserwacja brytyjskich dążeń kolonizatorskich. W przypadku twórczości Josepha Conrada Burden stara się jednak zdystansować od zarzutów innych badaczy, oskarżających pisarza o rasizm (por. s. 46). Utwory poświęcone podróży są, rzecz jasna, pisarstwem podejmującym próbę opisu konkretnych miejsc - m.in. Archipelagu Malajskiego, Konga, Ameryki Południowej, ale także odwiedzonych przez pisarza miast. Conradowska topografia staje się przenośnią egzotyczne rejony, morze, wielkie ośrodki miejskie (będące metaforą degeneracji zachodniej cywilizacji) - przestrzenie szczegółowo omówione i zestawione w pierwszym rozdziale pozwoliły na wskazanie dwóch odsłon modernizmu 
w twórczości Conrada, a także przewijającej się w całym studium Roberta Burdena opozycji między cywilizacją, postępem, nowoczesnością a powrotem do korzeni, tradycją, naturą.

Podobne wątki wskaże autor w twórczości bohatera drugiego rozdziału zatytułowanego The Heuristic Value of Travel and Place, E.M. Forstera. Naczelne miejsce w rozważaniach na temat jego zainteresowań literackich zajmuje napięcie między byciem w domu a podróżą, która pozwala na krytyczne spojrzenie na miejsce swojego pochodzenia. W przeciwieństwie do poprzedniego rozdziału przedmiotem zainteresowania Burdena w przypadku twórczości Forstera są nie tylko powieści jego autorstwa, ale także dzienniki podróży, stanowiące swoiste przewodniki (przeznaczone jednak dla przygotowanego i wykształconego turysty), opisujące między innymi wyjazdy do Włoch, Grecji, Egiptu. W jego tekstach, jak pisze Burden, "geografia staje się kluczem do poznania historii" (s. 68). Podróż do przeszłości, spotkania z „duchami” antycznych zakątków są zaś krytyką jałowej, odartej z historycznych tradycji nowoczesności. Interesujące Burdena w dorobku wszystkich autorów zderzenie wyobrażeń na temat innych zakątków świata z rzeczywistością (a co za tym idzie uproszczonego, masowego spojrzenia turystycznego ze spojrzeniem podróżniczym, dzięki któremu jest szansa na poznanie prawdziwej przestrzeni, niedostępnej turystom) jest znaczącym motywem rozważań na temat „indyjskich” tekstów Forstera (zebranych w tomie The Hill of Devi). „Wakacje od brytyjskości", jak konkluduje Burden, w twórczości Forstera są okazją do celebracji różnic, ucieczki od ograniczeń i przynależności (przede wszystkim klasowych, obyczajowych, „heteronormatywnych”) typowych dla rodzimej przestrzeni. Stają się także punktem wyjścia do opowieści o współczesnej tożsamości oraz idealizacji przeszłości (dostrzeganej przez Forstera także podczas podróży na brytyjską prowincję). Forster nie unika symbolicznych opozycji wy- wołanych opisem obserwowanego krajobrazu (light-dark, interior-exterior). Podróż Forstera ma przede wszystkim wartość heurystyczną jest szansą na „poszerzenie kulturalnych i seksualnych horyzontów” (s. 106).

Kolejnym bohaterem rozważań Burdena jest D.H. Lawrence (Travel, Otherness and the Sense of Place). Obserwowanie jego podróży (do Niemiec, Szwajcarii, Włoch, Australii, Nowego Meksyku i Meksyku) jest w rzeczywistości analizą kondycji modernistycznego artysty jako osoby pozbawionej miejsca, poszukującej własnej przestrzeni. Autentyzm literackich opisów wynika między innymi z faktu, że teksty Lawrence'a powstawały na bieżąco, podczas podróży, pod wpływem konkretnych miejsc i krajobrazów, ograniczających człowieka przestrzeni zamkniętych i uwalniających go przestrzeni otwartych. Pragnienie podróży pozwala zaspokoić tęsknotę za powrotem do nieskażonej nowoczesnością krainy, jest poszukiwaniem raju utraconego, które przekształca się w krytykę nowoczesności, zaburzającej tradycyjne układy, wartości i naturalne więzi. Pogoń za „Innym” i spotkanie z „duchami” odwiedzanych miejsc stają się u Lawrence'a jedyną drogą do zdefiniowania własnej tożsamości. Fascynacja odległymi zakątkami, w których przetrwały pierwotne społeczności, jest tęsknotą za zaburzonym przez nowoczesność życiem w harmonii z naturą. Opisy krajobrazów u Lawrence'a wywołują także inne skojarzenia, stają się odzwierciedleniem stanów emocjonalnych człowieka, jego kondycji psychicznej, problemów z dookreśleniem seksualnej tożsamości. Idealizujące, romantyczne deskrypcje pejzaży, zwyczajów, zakątków nie dają jednak odpowiedzi na pytanie, które nurtuje Burdena w odniesieniu do twórczości wszystkich omawianych autorów czy bez względu na ich otwartość (na inność) są w stanie wyjść poza perspektywę imperialną, przekroczyć ramy „imperialnych wyobrażeń" (Mary Louise Pratt), które zdominowały na przełomie wieków zachodnie spojrzenie? 
Ostatnie dwa rozdziały pracy pozwalają na zmianę perspektywy na amerykańską. W części czwartej rozprawy (Henry James: Journeys of Expatriation) badacz proponuje spojrzenie na „transgraniczne motywy” w twórczości faktograficznej i literackiej Henry'ego Jamesa, zwracając uwagę na fundamentalne znaczenie podróży dla jego pisarstwa - podróży, która współtworzy narrację i pozwala na odnalezienie wyjściowej dla tekstu opowieści (sam James określał ten rodzaj wyprawy mianem story seeker's journey, por. s. 156). Pragnienie podróży do Europy, krytyka nieodwracalnych zmian, które przyniosła nowoczesność, radykalne przeciwstawienie masowej, komercyjnej, powierzchownej turystyki wnikliwemu, pogłębionemu poznaniu, refleksja nad czasem i przemijaniem (widoczna między innymi w opisach ruin), poszukiwanie przeszłości przez człowieka z „kraju bez przeszłości”, rozumienie podróży jako doświadczenia estetycznego - wszystkie te wątki znajdują odzwierciedlenie w tekstach amerykańskiego pisarza i zostały wnikliwie przeanalizowane przez Roberta Burdena.

Książkę zamyka rozdział poświęcony pisarce Edith Wharton (The Aesthetic Value of Travel). Autor ponownie, wychodząc od krótkiej prezentacji życiorysu, zwraca uwage na fundamentalny dla tekstów Wharton motyw osobistego doświadczenia podróży, która staje się swoistym testem ze znajomości kultury, otwartości na inność i różnorodność (s. 197). Jej teksty, w których fikcyjni bohaterowie obdarzeni zostali poznawczymi możliwościami rozumienia innych kultur, prezentują wreszcie kobiecą perspektywę. Burden konkluduje, że w twórczości pisarki podróż staje się przełamaniem genderowej konwencji, ucieczką od rutyny narzuconej kobietom przez kulturowo i obyczajowo przypisane role. Obszerny fragment rozdziału stanowi zestawienie twórczości Wharton i Jamesa (którzy znali się osobiście, co, jak podkreśla autor, nie pozostaje bez wpływu na ich literacki dorobek). Istotnym punktem analizy Burdena jest zwrócenie uwagi na fakt, że mimo iż akcja najsłynniejszych tekstów pisarki (The House of Mirth, The Custom of the Country, The Age of Innocence) sytuuje się przede wszystkim w Nowym Jorku, ich problematyka w dużej mierze dotyczy podróży ( $w$ sensie literackim, metaforycznym bądź dosłownym).

Pobieżne omówienie poszczególnych rozdziałów książki Travel, Modernism and Modernity nie oddaje wnikliwości, z jaką jej autor zmierzył się nie tylko z sygnalizowanymi w tytule problemami. Pogłębiona analiza wybranych tekstów Conrada, Forstera, Lawrence'a, Jamesa i Wharton prowadzi do interpretacji wielu innych wątków w twórczości modernistów. Szerokie odwołania w pracy Burdena do różnorodnych, wnikliwie przedstawionych kontekstów, konsekwentne, wieloaspektowe wskazywanie przestrzeni i podróży jako czynników kształtujących świadomość kulturową w okresie modernizmu sprawiają, że mimo wielu publikacji na temat twórczości wybranych autorów, Travel, Modernism and Modernity stanowi dzieło nowatorskie, pomagające spojrzeć na dorobek epoki z innej perspektywy. To książka, która jawi się jako summa dotychczasowych ujęć, jednocześnie proponuje interesujące spojrzenie na archetypiczny i od wieków bliski literaturze motyw podróży, wędrówki, poszukiwania miejsca, a więc własnej tożsamości (zarówno indywidualnej, jak i narodowej). Mimo że opisywane w pracy Burdena teksty powstawały w początkach XX wieku, wydaje się, że dociekania autora są niezwykle aktualne także w odniesieniu do współczesności.

SŁOWA KLUCZOWE $\mid$ ABSTRAKT $\mid$ NOtA O AUTORZE 


\title{
SEOWA KLUCZOWE:
}

\author{
po d r ó $\dot{z}$ \\ i turystyka
}

\section{MODERNIZM}

\begin{abstract}
AbStrakT:
Recenzja prezentuje monografię Travel, Modernism and Modernity, autorstwa brytyjskiego badacza Roberta Burdena, wydaną w 2015 roku. Głównym celem omawianej pracy jest ponowne odkrycie i dogłębne przeanalizowanie modernistycznego pisarstwa podróży. Podstawą rozważań Burdena są literackie i nieliterackie teksty brytyjskich i amerykańskich pisarzy: Josepha Conrada (1957-1924), Edwarda Morgana Forstera (1879-1970), Davida Herberta Lawrence'a (1885-1930), Henry'ego Jamesa (1843-1916) i Edith Wharton (1862-1937). Ich dzieła stawały się już wielokrotnie przedmiotem analizy historyków i teoretyków literatury - to, co odróżnia pracę Burdena od rozważań innych badaczy, to przede wszystkim szerokie, kontekstowe ujęcie ich twórczości. Burden prezentuje sylwetki pisarzy, podkreśla rolę inspiracji autobiograficznych w ich pisarstwie, analizuje je w kontekście historycznym, społecznym i psychologicznym. Motyw podróży nie jest jedynym elementem łączącym poszczególne teksty omawiane przez Burdena - cała jego książka poświęcona jest wyszukiwaniu paraleli i korespondencji, a także elementów oryginalnych, wyróżniających twórczość każdego z pięciorga anglojęzycznych autorów. Omawiane studium należy potraktować jako doskonałe podsumowanie wcześniejszych ujęć, jednocześnie oferujące interesujące rozważania m.in. na temat archetypicznego motywu podróży, wędrówki i poszukiwania - zarówno miejsca, jak i tożsamości (indywidualnej oraz narodowej). Pomimo że teksty omawiane przez Burdena powstawały na początku XX wieku, trudno oprzeć się wrażeniu, iż rozważania autora omawianej monografii są niezwykle aktualne również współcześnie.
\end{abstract}




\section{PISARSTWO PODRÓŻY}

nowoczesność

\section{NOTA O AUTORZE:}

Urszula Kowalska-Nadolna - adiunkt Instytutu Filologii Słowiańskiej Uniwersytetu im. Adama Mickiewicza w Poznaniu. Jej główne zainteresowania badawcze to: współczesna literatura czeska, wydarzenia Praskiej Wiosny i ich wpływ na czeską kulturę, literaturę, historię i tożsamość narodową, emigracja czeska po roku 1968, literatura i polityka, pamięć historyczna i popkultura. Autorka dwóch monografii: „Tato noc nebude kratká”. Doświadczenie roku 1968 w czeskiej literaturze emigracyjnej (2015) oraz „Pan śpiewak świat widzi ponuro". Słowiański bard, popularny tekściarz czy ponadczasowy poeta? O twórczości Karla Kryla i Jacka Kaczmarskiego (2016). 